\title{
Development of a Rolling Process Design Tool for Use in Improving Hot Roll Slab Recovery
}

R. Couch, P. Wang

November 19, 2001

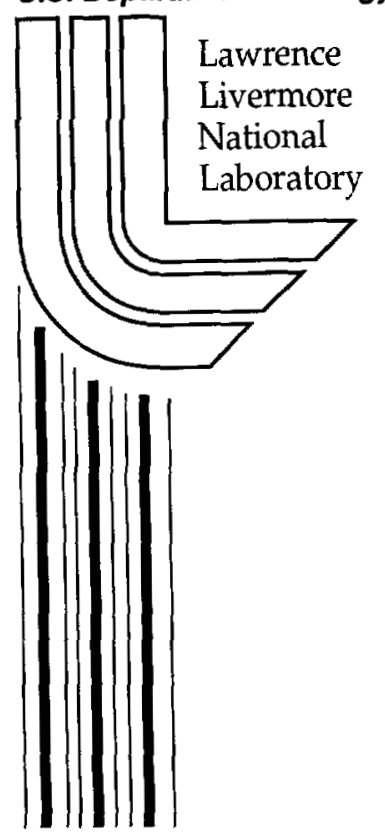




\section{DISCLAIMER}

This document was prepared as an account of work sponsored by an agency of the United States Government. Neither the United States Government nor the University of California nor any of their employees, makes any warranty, express or implied, or assumes any legal liability or responsibility for the accuracy, completeness, or usefulness of any information, apparatus, product, or process disclosed, or represents that its use would not infringe privately owned rights. Reference herein to any specific commercial product, process, or service by trade name, trademark, manufacturer, or otherwise, does not necessarily constitute or imply its endorsement, recommendation, or favoring by the United States Government or the University of California. The views and opinions of authors expressed herein do not necessarily state or reflect those of the United States Government or the University of California, and shall not be used for advertising or product endorsement purposes.

This work was performed under the auspices of the U.S. Department of Energy by the University of California, Lawrence Livermore National Laboratory under Contract No. W-7405-Eng-48.

This report has been reproduced directly from the best available copy.

Available electronically at http://www.doc.gov/bridge

Available for a processing fee to U.S. Department of Energy

And its contractors in paper from

U.S. Department of Energy

Office of Scientific and Technical Information

P.O. Box 62

Oak Ridge, TN 37831-0062

Telephone: (865) 576-8401

Facsimile: (865) 576-5728

E-mail: reports@adonis.osti.gov

Available for the sale to the public from

U.S. Department of Commerce

National Technical Information Service

5285 Port Royal Road

Springfield, VA 22161

Telephone: (800) 553-6847

Facsimile: (703) 605-6900

E-mail: orders@ntis.fedworld.gov

Online ordering: http://www.ntis.gov/ordering.htm

OR

Lawrence Livermore National Laboratory

Technical Information Department's Digital Library

http://www.llnl.gov/tid/Library.html 


\title{
Development of a Rolling Process Design Tool for Use in Improving Hot Roll Slab Recovery
}

\author{
Lawrence Livermore National Laboratory \\ Principal Investigator: Dr. Richard Couch \\ PO Box 808; L-99 \\ Livermore, CA 94550 \\ Phone: 925-422-1655 \\ FAX: 925-422-3389 \\ couch!@linl.gov \\ and by \\ Alcoa Incorporated \\ Principal Investigator: Dr. Paul Wang \\ Alcoa Technology Center \\ ATC-B \\ 100 Technical Drive \\ Alcoa Center, PA 15069 \\ Phone:724-337-2004 \\ FAX: 724-337-2005
}

Paul.Wang@alcoa.com

\section{Quarterly Report: Q4 FY01}

\section{LLNL Input}

A model of the 28-inch, laboratory mill at Alcoa Technical Center was constructed, and a preliminary calculation run using an estimated initial ingot size and pass schedule to assess the computational requirements for the simulations and to develop a procedure for adjusting the mill configuration and model boundary conditions between passes. The simulation was run through three passes, and the mechanical and contact thermal boundary conditions appear to be working appropriately. The figure shown below is a contour plot of the thermal field after three passes.

A summer student at LLNL studied the effects of the spatial discretization on the accuracy of the thermal contact solution. The results of this work provide a guide for selecting the proper element size to give a desired level of accuracy for the thermal solution. The mesh in the figure below is too coarse to guarantee that the transient temperature field is accurate to within 10 degrees. Additional mesh refinement is needed. In anticipation of this, it was confirmed that this calculation would run effectively in parallel on the Compaq cluster at LLNL.

This work was performed under the auspices of the U.S. Department of Energy by the University of California, Lawrence Livermore National Labortory under Contract No. W-7405-Eng-48. 


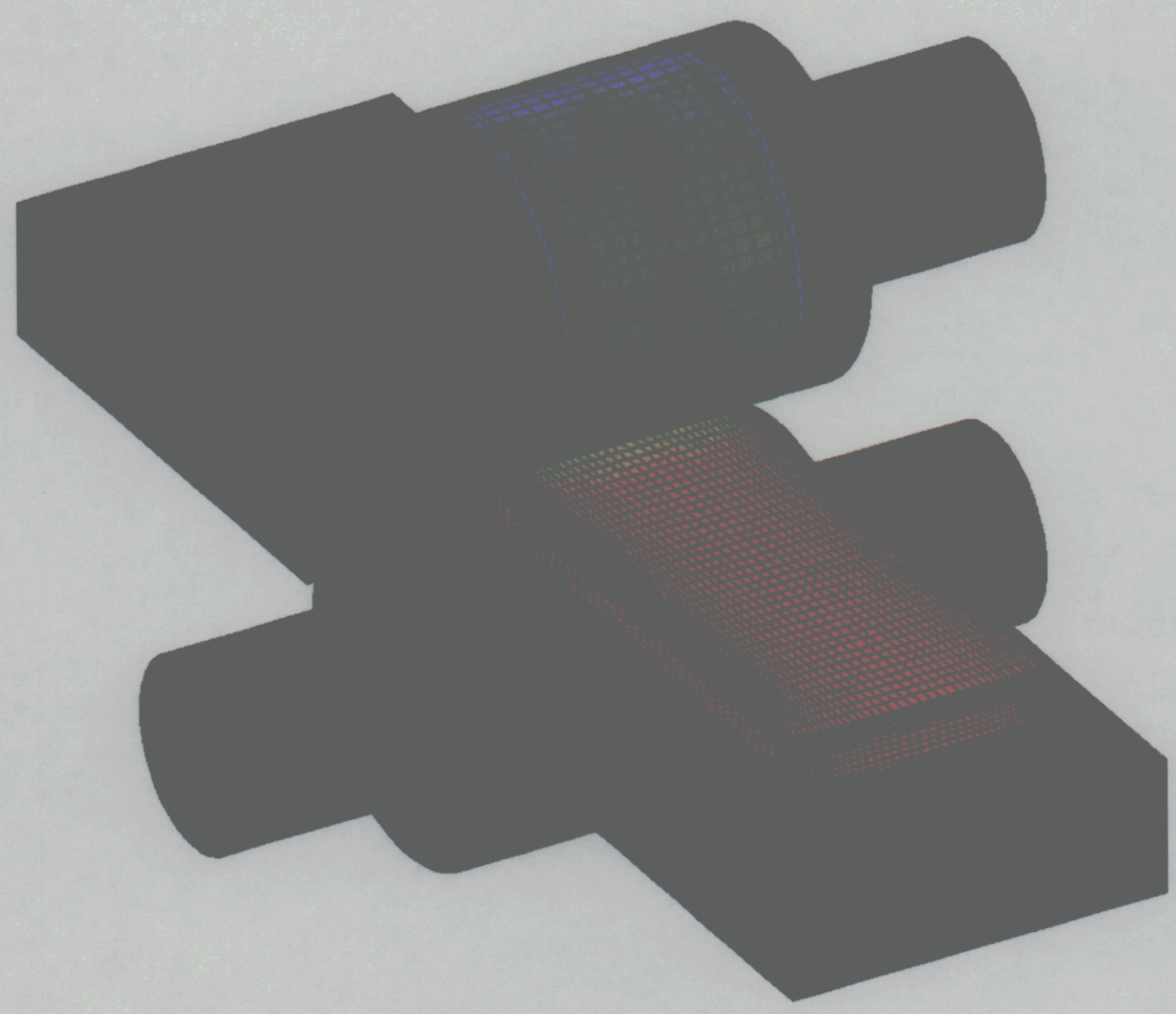

The actual ingot geometry and pass schedule were received from Alcoa late in the quarter and the geometry has been modified to account for the correct ingot size. Some aspects of the thermal treatment need further development. These include accounting for the interpass delay on heat conduction within the roll and incorporating film coefficient boundary conditions consistent with natural convection to the air and the coolant/lubricant sprayed on the roll. Appropriate film coefficients will be obtained from Alcoa.

\section{Alcoa Input}

- Determine material constitutive properties (Alcoa proprietary data):

The constitutive property of an aluminum alloy from $5 x x x$ series has been obtained by using the hot tensile testing fixture conducted at the Deformation Simulator at Alcoa Technical Center. 
The constitutive equation of this alloy was formatted in a hyperbolic sine type equation in terms of temperature, strain rate, and flow stress. Four material constants were determined.

- Characterize hot rolling process: boundary and initial conditions (protected CRADA information)

The boundary and initial conditions of hot rolling process were quantified from experiments conducted at the 28 " hot mill at Alcoa Technical Center. These conditions would include roll geometry, roll speed, initial roll temperature, slab geometry, and initial slab temperature. A rolling schedule of the alloy mentioned above was established for rolling experiments and for numerical simulation purpose.

Note:

1. Alcoa proprietary data means the data was developed by Alcoa before this CRADA activity started

2. Protected CRADA information means Alcoa data was produced in performance of this CRADA project. This data can not be released for 5 years

3. All data generated by LLNL under this CRADA project is restricted under the rules governed by "Protected CRADA Data" 
U.S. DEPARTMENT OF ENERGY FEDERAL ASSISTANCE PROGRAMIPROJECT STATUS REPORT
OMB Control No $1910-0400$

OMB Burden Disclosure Statement

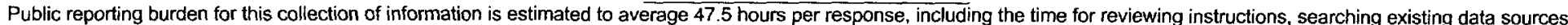

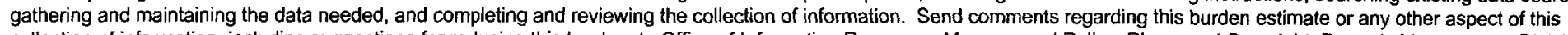

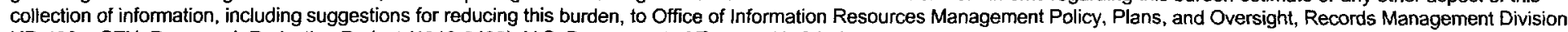

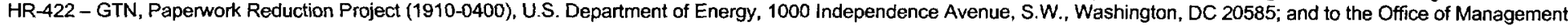
and Budget (OMB). Paperwork Reduction Project (1910-0400), Washington, DC 20503.

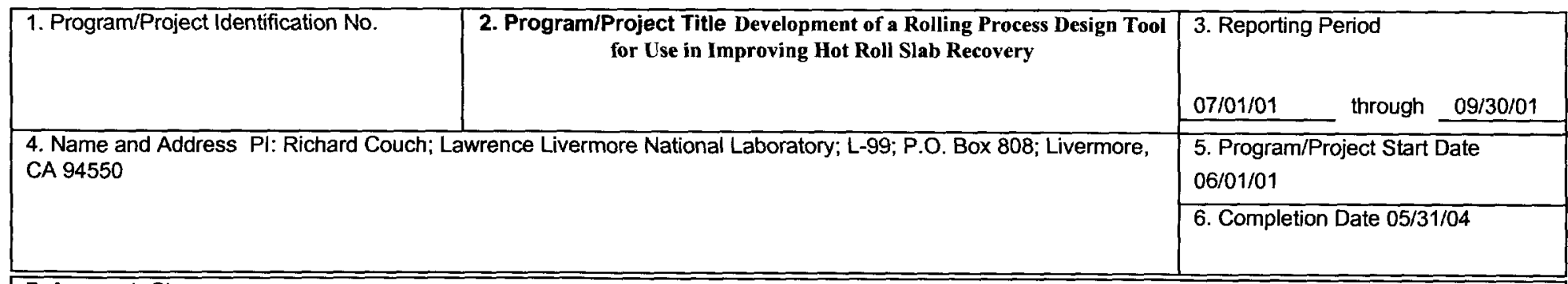

7. Approach Changes

$x$ None

8. Performance Variances, Accomplishments, or Problems

$x$ None

9. Open Items

$x$ None

10. Status Assessment and Forecast

$x$ No Deviation from Plan is Expected

11. Description of Attachments

$x$ None

12. Signature of Recipient and Date

13. Signature of U.S. Department of Energy (DOE) Reviewing Representative and Date 


\section{U.S. Department of Energy \\ Milestone Log}

Development of a Rolling Process Design Tool for Use in Improving Hot Roll Slab Recovery

\begin{tabular}{|c|c|c|c|}
\hline $\begin{array}{c}\text { Identification } \\
\text { Number }\end{array}$ & Description & $\begin{array}{c}\text { Planned Completion } \\
\text { Date }\end{array}$ & $\begin{array}{l}\text { Actual Completion } \\
\text { Date }\end{array}$ \\
\hline 1. & $\begin{array}{l}\text { Constitutive model } \\
\text { defined: PQ3 }\end{array}$ & $3 / 02$ & \\
\hline 2. & $\begin{array}{l}\text { Fracture model defined: } \\
\text { PQ5 }\end{array}$ & $9 / 02$ & \\
\hline 3. & $\begin{array}{l}\text { Friction model defined: } \\
\text { PQ3 }\end{array}$ & $3 / 02$ & \\
\hline 4. & $\begin{array}{c}\text { Finite element model } \\
\text { constructed: PQ4 }\end{array}$ & $6 / 02$ & \\
\hline 5. & $\begin{array}{c}\text { Rolling data produced: } \\
\text { PQ6 }\end{array}$ & $12 / 02$ & \\
\hline 6. & $\begin{array}{l}\text { Initial code validation } \\
\text { studies completed: PQ8 }\end{array}$ & $6 / 03$ & \\
\hline 7. & $\begin{array}{l}\text { Validate models in a } \\
\text { production } \\
\text { configuration: PQ10 }\end{array}$ & $12 / 03$ & \\
\hline 8. & $\begin{array}{l}\text { Complete parameter } \\
\text { study: PQ12 }\end{array}$ & $6 / 04$ & \\
\hline
\end{tabular}

